\title{
Biochar Can Enhance Potassium Fertilization Efficiency and Economic Feasibility of Maize Cultivation
}

\author{
Widowati $^{1} \&$ Asnah $^{1}$ \\ ${ }^{1}$ Tribhuwana Tunggadewi University, Malang, Indonesia \\ Correspondence: Widowati, Tribhuwana Tunggadewi University, Jl. Telaga Warna Blok C, Malang, Indonesia. \\ E-mail: widwidowati@gmail.com
}

Received: November 13, 2013 Accepted: December 9, $2013 \quad$ Online Published: January 15, 2014

doi:10.5539/jas.v6n2p24 URL: http://dx.doi.org/10.5539/jas.v6n2p24

\begin{abstract}
Field experiments were conducted to study the effect of biochar on potassium fertilizer leaching and uptake, efficiency and effectiveness of $\mathrm{K}$ fertilization, and economic viability of farming maize. Thirty tons ha ${ }^{-1}$ of biochar prepared from organic waste was applied to an Inceptisol. The experiment was arranged in a randomized block design with 7 treatments, namely control (without biochar and $\mathrm{KCl}$ ), $\mathrm{K} 1\left(200 \mathrm{~kg} \mathrm{ha}^{-1} \mathrm{KCl}\right.$ ), BK0 (biochar, without $\mathrm{KCl}$ ), BK1/4 (biochar $\left.+50 \mathrm{~kg} \mathrm{ha}^{-1} \mathrm{KCl}\right), \mathrm{BK} 1 / 2\left(\right.$ biochar $\left.+100 \mathrm{~kg} \mathrm{ha}^{-1} \mathrm{KCl}\right), \mathrm{BK} 3 / 4$ (biochar $+150 \mathrm{~kg} \mathrm{ha}{ }^{-1} \mathrm{KCl}$ ), and BK1 (biochar $+200 \mathrm{~kg} \mathrm{ha}^{-1} \mathrm{KCl}$ ) and three replicates for each treatment. The results suggest that biochar could replace and reduce $\mathrm{KCl}$ fertilizer. Biochar application increased the availability of nutrients by $69-89 \%$ for $\mathrm{K}^{+}$, $61-70 \%$ for $\mathrm{Ca}^{++}, 39-53 \%$ for $\mathrm{N}$ total, $179-208 \%$ for $\mathrm{P}$, and $14-184 \%$ for $\mathrm{K}$. The results showed that the sole application of biochar increased maize production $\left(6.24 \mathrm{Mg} \mathrm{ha}^{-1}\right)$ by $14 \%$ compared sole application of $\mathrm{KCl}$ fertilizer $\left(5.45 \mathrm{Mg} \mathrm{ha}^{-1}\right)$. In contrast, dual application of biochar and 75\% lower dosage of $\mathrm{KCl}$ fertilizer application increased maize production by $29 \%$. Application of biochar and $\mathrm{KCl}$ fertilizer at the rate of $50 \mathrm{~kg}^{-1}$ resulted in the highest relative agronomic effectiveness $(137 \%)$ and $\mathrm{K}$ fertilizer efficiency $(18 \%)$. This application rate was also superior both technically and economically as assessed in terms of production $\left(7.02 \mathrm{Mg} \mathrm{ha}^{-1}\right)$, value of sales (revenue; IDR 19,305 million ha ${ }^{-1}$ ), income (IDR 8,663 million ha ${ }^{-1}$ ), and economic feasibility (R/C, 1.8).
\end{abstract}

Keywords: biochar, leaching, uptake, efficiency, effectiveness, economic feasibility

\section{Introduction}

Potassium $(\mathrm{K})$ is an essential nutrient for plant growth and cannot be replaced by other elements. The function of $\mathrm{K}$ is associated with increased root growth and tolerance to drought, cellulose formation, enzyme activity, photosynthesis, transportation of sugar and starch, increase protein content of plants, maintain turgor, reduce water loss, and to protect plants against diseases and nematodes (Thomson, 2008). The high mobility of K results in its loss through leaching due to heavy rainfall. Cooke (1985) showed that high amounts of K are lost (172 kg $\left.\mathrm{ha}^{-1}\right)$ followed by $\mathrm{N}\left(260 \mathrm{~kg} \mathrm{ha}^{-1}\right)$ and $\mathrm{P}\left(46 \mathrm{~kg} \mathrm{ha}^{-1}\right)$ in maize cultivation.Nutrition content in maize plant yielding maize at $9.45 \mathrm{Mg} \mathrm{ha}^{-1}$ were $3.9 \mathrm{~kg} \mathrm{ha}^{-1}$ (seed) and $157 \mathrm{~kg} \mathrm{ha}^{-1}$ (cob) (Cooke, 1985). Fertilization is an effort to improve crop yield. The use of inorganic and organic fertilizers can increase soil fertility. In tropical regions with high rainfall, the soils are low in $\mathrm{K}$ due to the rapid mineralization of organic matter (Jenkinson \& Ayanaba, 1977). The weakness of inorganic fertilizer is the accessibility for poor farmers is low (Garrity, 2004) and fertilization efficiency is low (Baligar \& Bennett, 1986). One of cause the low fertilization efficiency is not all fertilizer put into the soil can be absorbed by the plant. The plant absorb potassium at 50 to $70 \%$ (Tisdale $\&$ Nelson, 1975).

According to study conducted by Brady (1992), most potassium added to the soil will be fixed in the spaces between clay lattice and plants can utilize only 1-2\%. Meanwhile, organic fertilizers can increase fertilization efficiency. However, in tropics organic fertilizers are decomposition rapidly. In contrast, black carbon (C) or biochar is much more stable. One way to overcome problems of soil fertility and $\mathrm{K}$ availability is by adding biochar. Biochar is produced from biomass pyrolysis. Biochar is a material containing hydrocarbon aromatic polycyclic carbon with functional groups (Schmidt \& Noack, 2000; Preston \& Schmidt, 2006; Krull et al., 2009; Chintala et al., 2013). Biochar has surface area and porosity which are significant in improving water holding capacity, adsorption, and nutrient retention (Downie et al., 2009; Sohi et al., 2010; Chintala et al., 2013). Biochar can affect soil structure, texture, porosity, particle size distribution, and density so it can improve aerase, water 
storage capacity and microbes, and nutrient availability in the root zone of plants (Amonette \& Joseph, 2009). Application of biochar leads to changes in $\mathrm{pH}$, electrical conductivity (EC), cation exchange capacity (CEC), and nutrient availability (Liang et al., 2006; Gundale \& DeLuca, 2007; Warnock et al., 2007). Biochar can reduce N leaching and improve $\mathrm{N}$ use efficiency (Chintala et al., 2013; Steiner et al., 2008; Widowati et al., 2012). The problem is whether biochar can reduce or replace $\mathrm{KCl}$ fertilizer so it can streamline potassium fertilization on maize plants. Based on the problem mentioned, a research was conducted to study the effect of biochar and potassium rate application, toward the efficiency and effectivity of fertilization, and also economic feasibility of maize cultivation business. It is hoped that biochar can reduce or replace the usage of $\mathrm{KCl}$ fertilizer that the need of potassium fertilizer can be reduced, therefore increasing the revenue of the cultivation business.

\section{Method}

Biochar was prepared by pyrolysis method in Bioenergy Laboratory of Tribhuwana Tunggadewi University from organic waste. The raw materials for biochar preparation were obtained form of organic waste (mostly consist of plant materials) of UPTD of Hygiene Waste Department of Malang City. These materials were sun dried to reach water content of about $17 \%$ and then heated in the pyrolysis reactor at temperature of $500^{\circ} \mathrm{C}$ for 2 hours 5 minutes. The characteristics city waste and biochar are presented in Widowati et al. (2011). Biochar $\mathrm{pH}$ was determined by the method of Amedna et al. (1977), total C by ASTM method (2006), and for N, P, K, Ca, Mg was employed the method described by Masulili et al. (2010). Prepared biochar was applied to the field at the rate of $30 \mathrm{Mg} \mathrm{ha}^{-1}$ after 2 weeks of incubation. The experimental design used was randomized block design. All treatments received urea and $\mathrm{SP}_{36}$ fertilizer at the rate of $90 \mathrm{~kg} \mathrm{~N} / \mathrm{ha}$ and $100 \mathrm{~kg} \mathrm{P}_{2} \mathrm{O}_{5} / \mathrm{ha}$. Fertilization was done 6 days after planting (DAP), namely for the $\mathrm{SP}_{36}$ and $\mathrm{KCl}$, whereas, urea applied twice i.e. 1/3 part on 6 DAP and 2/3 part on 4 weeks after planting (WAP). Potassium fertilizer was given at 1 and $4 \mathrm{WAP}$ and the treatments included an appropriate control, $\mathrm{K} 1(\mathrm{KCl} 200 \mathrm{~kg} / \mathrm{ha}), \mathrm{BK} 0$ (biochar, without KCl), BK 1/4 (biochar $\left.+\mathrm{KCl} 50 \mathrm{~kg} \mathrm{ha}^{-1}\right), \mathrm{BK} 1 / 2($ biochar $+\mathrm{KCl} 100$ $\mathrm{kg} \mathrm{ha}^{-1}$ ), BK 3/4 (biochar+ KCl $150 \mathrm{~kg} \mathrm{ha}^{-1}$ ), and BK 1 (biochar $+\mathrm{KCl} 200 \mathrm{~kg} \mathrm{ha}^{-1}$ ). Each treatment was replicated three times. In all there were 21 plots measuring $3 \times 4 \mathrm{~m}^{2}$. Two weeks after biochar application maize (variety Bisi 12) was planted with an interplant distance of $80 \times 25 \mathrm{~cm}$ resulting in a plant density of 50,000 plants ha ${ }^{-1}$.Maize was harvested when the cob was dry while the seeds already glisen and reddish yellow, at the age of 110 days. At harvest (110 days after planting) soil samples were collected for analysing soil properties at the end of the experiment. Analysis of soil properties included soil organic matter (Walkley and Black wet oxidation method) (Soil Survey Laboratory Staff, 1992), N (Kjedahl), $\mathrm{P}$ available (Bray 1), $\mathrm{K}$ available $\mathrm{NH}_{4} \mathrm{OAC}$ (buffered at $\mathrm{pH}$ 7.0), $\mathrm{K}$ unavailable ( $\mathrm{HCl} 25 \%$ ), and soil texture (sedimentation). Further analysis conducted on plant height, stem diameter (using caliper), leaf area (using leaf area meter), cob length and diameter, dry weight of: (stems, leaves, total above-ground plant, and maize), $\mathrm{K}\left(\mathrm{HNO}_{3}+\mathrm{HClO}_{4}\right)$ level in leaves and stems at maximum vegetation (10 $\mathrm{mst}), \mathrm{K}$ level inseeds at harvest and $\mathrm{K}$ uptake efficiency. The efficiency of $\mathrm{K}$ fertilization is calculated from the dry weight increase of crop yields for each weight unit of K, provided in the fertilizer material (Witt \& Dobermann, 2006). To measure the effectiveness of organic fertilizer it is used the calculation of Relative Agronomic Effectiveness (RAE) i.e. the ratio between the increase in results using a certain fertilizer to the increase in results using standard fertilizer multiplied by 100 (Ghosal et al., 2003). Observation of dry weight was made by drying the plant material in an oven at $70^{\circ} \mathrm{C}$ for $2 \times 24$ hours. $\mathrm{K}$ uptake of maize plants was determined by the weight of dry biomass and $\mathrm{K}$ levels.

The data were analyzed by using GENSTAT Release 12.2 software. Randomized group design analysis was done and continued with LSD test to see the differences among treatments.Furthermoreregression analysis was done to see the relationship among parameters. The economic feasibility of maize cultivation with biochar and dosage of K fertilizer were done by calculating the cost of production, revenue, income, and the feasibility of the business itself.

\section{Results and Discussion}

\subsection{Soil and Characteristics of Organic Waste Biochar}

The study was conducted during wet season (January-May, 2012) so there was no irrigation activity. The rainfall data taken from the climatology station of Karangploso Malang were $287 \mathrm{~mm}$ (January), $287 \mathrm{~mm}$ (February), 422 $\mathrm{mm}$ (March), $66.3 \mathrm{~mm}$ (April), and $24.12 \mathrm{~mm}$ (May). There was no pest and plant diseases encountered during the study. Prior the biochar application the soil had $\mathrm{pH}\left(\mathrm{H}_{2} \mathrm{O}\right) 6: 37$, low $\mathrm{C}$ organic content $(1,46 \%)$, low $\mathrm{N}(0.19 \%)$, sufficient P (24.38 mg kg$\left.{ }^{-1}\right)$, very low $\mathrm{K}\left(0.08 \mathrm{cmol} \mathrm{kg}{ }^{-1}\right)$, high $\mathrm{Mg}\left(3.81 \mathrm{cmol} \mathrm{kg}^{-1}\right)$, low Ca $\left(4.49 \mathrm{cmol} \mathrm{kg}^{-1}\right)$, and cation exchange capacity $\left(14.02 \mathrm{cmol} \mathrm{kg}^{-1}\right)$. Dusty clay was used from the depth of $0-20 \mathrm{~cm}$. The biochar organic waste came from urban organic waste (consist of the remaining leaves and stems of vegetables and fruits, maize, grass, leaves, trees, and ornamental plants) taken from Solid Waste Management Unit of Sanitation Department of Malang City. Biochar was produced from organic waste with $17-19 \%$ water content. The production was done at 
temperature of $300{ }^{\circ} \mathrm{C}$, within 3-4 days. The organic waste characteristic were $\mathrm{pH}\left(\mathrm{H}_{2} \mathrm{O}\right)$ 9.6, $\mathrm{C}$ organic content (31.41\%), N (1.67\%), P (0.72\%), K (0.93\%), Mg (0.61 $\left.\mathrm{cmol} \mathrm{kg}^{-1}\right), \mathrm{Ca}\left(1.08 \mathrm{cmol} \mathrm{kg}^{-1}\right)$, and cation exchange capacity $\left(23.87 \mathrm{cmol} \mathrm{kg}^{-1}\right)$. Biochar was sift with a 10-20 mesh sieve, before application.

\subsection{Vegetative Growth of Maize Plants}

The plant growth at the maximum vegetative phase does not show any difference among treatments in terms ofplant height and stem diameter. However, there are difference on the leaf area among treatments (Table 1). The application of either biochar without $\mathrm{K}$ fertilizer or with low rate of $\mathrm{K}$ fertilizer $\left(50 \mathrm{~kg} \mathrm{ha}^{-1}\right)$, is better than solely $\mathrm{K}$ fertilizer. The biochar application of $30 \mathrm{Mg} \mathrm{ha}^{-1}$, either without $\mathrm{K}$ fertilizer (BK0) or with $\mathrm{K}$ fertilizer at the rate of $\left(50-150 \mathrm{~kg} \mathrm{ha}^{-1}\right)$, yield the same plant height and stem diameter as $\mathrm{K}$ fertilizer at the rate of $200 \mathrm{~kg} \mathrm{ha}^{-1}$. However, biochar application of $30 \mathrm{Mg} \mathrm{ha}^{-1}$ with $\mathrm{K}$ fertilizer at the rate of $200 \mathrm{~kg} \mathrm{ha}^{-1}$ (BK1) yield the lowest leaf area. It also yield the lowest dry weight of leaf, stem, and total plant, which are the same, as $\mathrm{K}$ fertilizer addition at the rate of $200 \mathrm{~kg} \mathrm{ha}^{-1}(\mathrm{~K} 1)$ (Table 2).

Table 1. Plant height mean, stem diameter, leaf area, leaf dry weight, stem and total plant at maximum vegetative growth

\begin{tabular}{lllllll}
\hline Treatment & $\begin{array}{l}\text { Plant Height } \\
(\mathrm{cm})\end{array}$ & $\begin{array}{l}\text { Stem Diameter } \\
(\mathrm{cm})\end{array}$ & $\begin{array}{l}\text { Leaf area } \\
\left(\mathrm{cm}^{2}\right)\end{array}$ & $\begin{array}{l}\text { Leaf BK } \\
\left(\mathrm{Mg} \mathrm{ha}^{-1}\right)\end{array}$ & $\begin{array}{l}\text { BK Trunk } \\
\left(\mathrm{Mg} \mathrm{ha}^{-1}\right)\end{array}$ & $\begin{array}{l}\text { BK Total Plant } \\
\left(\mathrm{Mg} \mathrm{ha}^{-1}\right)\end{array}$ \\
\hline K1 & 177.33 & 2.53 & $6104.44 \mathrm{ab}$ & $2.02 \mathrm{a}$ & $2.60 \mathrm{a}$ & $4.62 \mathrm{a}$ \\
BK0 & 184.00 & 2.70 & $6485.57 \mathrm{c}$ & $2.33 \mathrm{~b}$ & $3.23 \mathrm{c}$ & $5.56 \mathrm{c}$ \\
$\mathrm{BK} 1 / 4$ & 184.00 & 2.83 & $6579.11 \mathrm{c}$ & $2.31 \mathrm{~b}$ & $3.72 \mathrm{~d}$ & $6.03 \mathrm{~d}$ \\
$\mathrm{BK} 1 / 2$ & 184.67 & 2.77 & $6462.45 \mathrm{bc}$ & $2.28 \mathrm{~b}$ & $3.11 \mathrm{bc}$ & $5.39 \mathrm{c}$ \\
$\mathrm{BK} 3 / 4$ & 177.00 & 2.73 & $6218.29 \mathrm{bc}$ & $2.22 \mathrm{~b}$ & $2.82 \mathrm{ab}$ & $5.04 \mathrm{~b}$ \\
BK1 & 176.33 & 2.50 & $5836.09 \mathrm{a}$ & $1.99 \mathrm{a}$ & $2.55 \mathrm{a}$ & $4.54 \mathrm{a}$
\end{tabular}

Means followed by the same letters in the same column are not significantly different $(\mathrm{p}=0.05)$.

Biochar with $\mathrm{K}$ fertilizer at the rate of $50 \mathrm{~kg} \mathrm{ha}^{-1}$, yields the highest dry weight of stems and total weight. According to Baronti et al. (2010), the highest dry matter increase (120\%) is obtained on biochar application at the rate of $60 \mathrm{Mg} \mathrm{ha}^{-1}$, any higher rate would decreases biomass. The biochar application and $\mathrm{K}$ fertilizer with increased rate $\left(100,150,200 \mathrm{~kg} \mathrm{ha}^{-1}\right)$, lowers the dry weight of stem as well as total plant weight. The biochar application without $\mathrm{K}$ fertilizer (BK0) yields better dry weight of leaves, stems, and total plant, compared to the application of $\mathrm{K}$ fertilizer only (K1) (Table 1).

\subsection{Uptake and Efficiency of Potassium Fertilization in Maize Plants}

$\mathrm{K}$ uptake in seeds did not show any differences among treatments, however there were differences found in leaves and stems. Biochar application without $\mathrm{K}$ fertilizer (BK0) results in higher $\mathrm{K}$ uptake in the leaves, than other treatments (Table 2). K uptake in the leaves increases $128 \%$ with biochar application only. Higher K uptake in the seeds and stems meanshigher efficiency of $\mathrm{K}$ fertilizer, with the value of $\mathrm{R}^{2}$ in successive was 0.703 and 0.926 . However, when biochar was combined with $\mathrm{K}$ fertilizer $\left(100-200 \mathrm{~kg} \mathrm{ha}^{-1}\right)$ then there was decrease in $\mathrm{K}$ uptake in the stems by $4-92 \%$. Biochar without $\mathrm{K}$ fertilizer and biochar with $\mathrm{K}$ fertilizer at the rate of $50 \mathrm{~kg} \mathrm{ha}^{-1}$, yields the same K uptake in the stems. K uptake increases since biochar can reduce leaching and increase nutrient availability (Chan et al., 2007; Yamato et al., 2006; Widowati et al., 2011). The addition of higher rate K fertilizer (100, 150, $200 \mathrm{~kg} \mathrm{ha}^{-1}$ ) will reduce the $\mathrm{K}$ uptake both in the leaves and stems (Figure 1). 


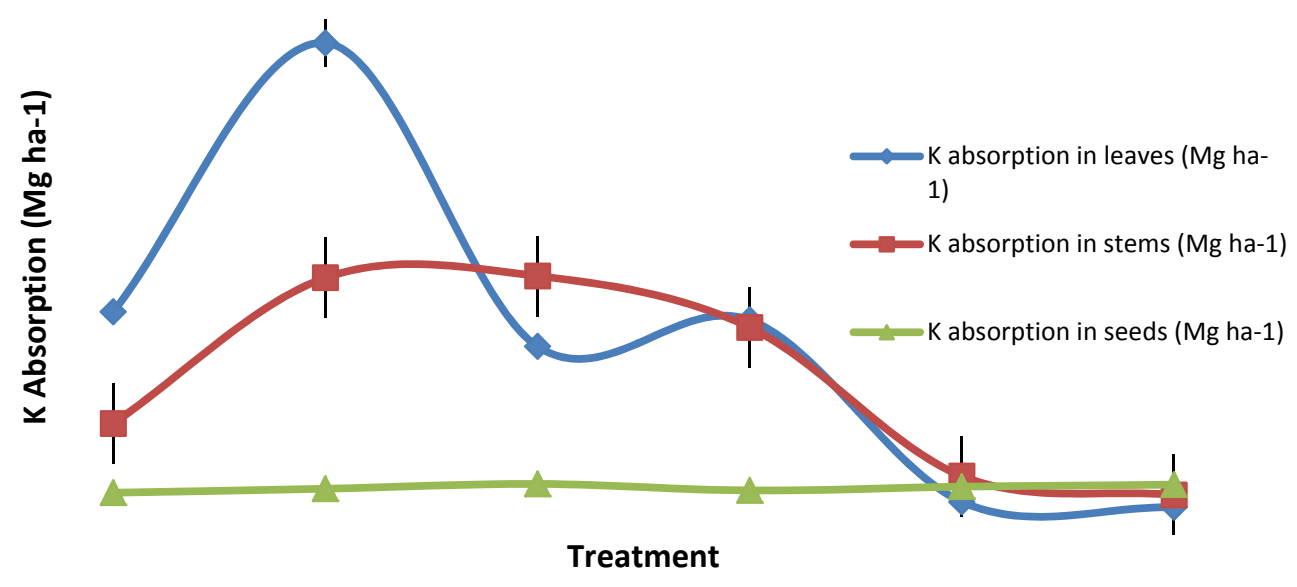

Figure 1. Potassium uptake in leaves and stems when vegetative growth maximally and potassium uptake in seeds at harvest time

The efficiency of fertilization as the utility to calculate the use of $\mathrm{K}$ fertilizer in the plant production. The highest $\mathrm{K}$ fertilizer efficiency $(18 \%)$ is in the biochar application with $\mathrm{K}$ fertilizer $\left(50 \mathrm{~kg} \mathrm{ha}^{-1}\right)$. Biochar application with increased $\mathrm{K}$ rate up to $200 \mathrm{~kg} \mathrm{ha}^{-1}$ will decrease the fertilization efficiency of $\mathrm{K}$. The efficiency of $\mathrm{K}$ fertilization on Biochar with $\mathrm{K}$ fertilizer, at the rate of $150-200 \mathrm{~kg} \mathrm{ha}^{-1}$, is not different compared to the application of $\mathrm{K}$ fertilizer only $\left(200 \mathrm{~kg} \mathrm{ha}^{-1}\right)$ (Figure 2). The relationship between biochar with various rate of $\mathrm{K}$ fertilizer and $\mathrm{K}$ fertilization efficiency is shown in Figure 3. The higher the rate of $\mathrm{K}$ fertilizer, the lower efficiency of $\mathrm{K}$ fertilizer, with value of $\mathrm{R}^{2}=0.907$. Biochar application can reduce the rate of $\mathrm{K}$ fertilizer and increase the efficiency of $\mathrm{K}$ fertilizer.

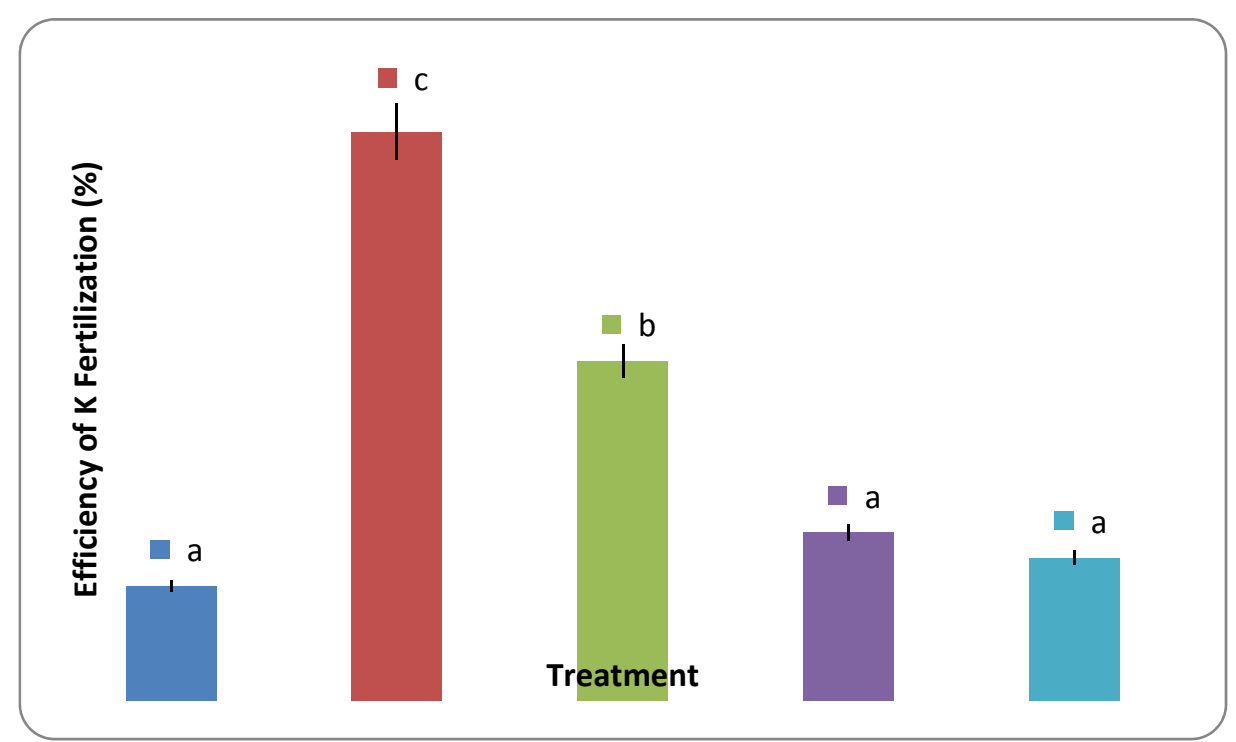

Figure 2. Effects of biochar and dosage of $\mathrm{K}$ fertilizer to efficiency of $\mathrm{K}$ fertilization on maize result 


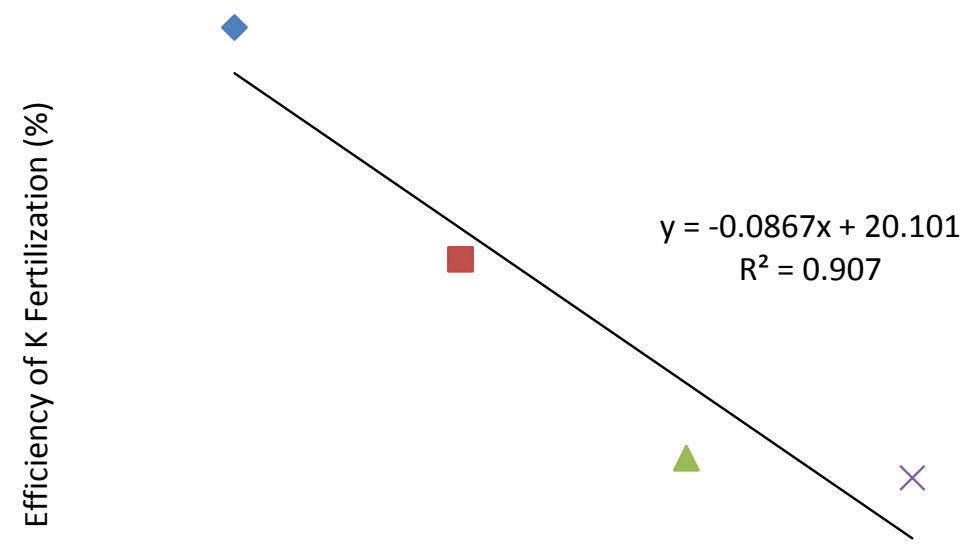

Biochar in various Dosage of K Fertilization $\left(\mathrm{kg} \mathrm{ha}^{-1}\right)$

Figure 3. Relationship between Biochar in various Dosage of K Fertilization and Efficiency of K Fertilization

3.4 The Effects of Biochar and Potassium Fertilizer Rate Toward the Result Component, Maize Yield, and Relative Agronomic Effectiveness (RAE)

The components of maize yield and dry maize results show no difference among treatments (Table 2). As observed by Major et al. (2010), during 4 years, maize yield does not increase significantly in the first year after biochar application of $20 \mathrm{Mg} \mathrm{ha}^{-1}$ in the Oxisol. In the second, third and fourth year respectively, there is maize yield increase in successive $28 \%, 30 \%, 140 \%$ compared to controls. Compared to the application without biochar (K1), the biochar application yield increases 11-16\% (long-cob), 5-9\% (cob diameter), and 2-6\% (weight of 1000 grains). There is no difference among treatments on the dry corn yield, However there is an increase of $14 \%$ with the application of biochar at $30 \mathrm{Mg} \mathrm{ha}^{-1}$ compared to the $\mathrm{K}$ fertilizer application at the rate of $200 \mathrm{~kg} \mathrm{ha}^{-1}$. Biochar application can enhance the nutrient reserves in the root zone, reduce leaching, and increase yields. The increases of yields in successive is $10 \%$ and $6 \%$ for wheat and maize after application biochar of $10 \mathrm{Mg} \mathrm{ha}^{-1}$ (Baronti et al., 2010).

Biochar application with $\mathrm{K}$ fertilizer at the rate of $50 \mathrm{~kg} \mathrm{ha}^{-1}$ (BK1/4) can increase the dry maize yield by $29 \%$. These results are in line with the best maximum vegetative growth (dry weight plant) in the treatment of BK1/4. The further increase in fertilizer rate causes the dry maize yield decrease $6-20 \%$. The biochar application with $\mathrm{K}$ fertilizer at the rate of $100 \mathrm{~kg} \mathrm{ha}^{-1}$ (BK1/2) shows the lowest increase of dry maize (3\%) and low K uptake in the seed is $7 \%$, while the other treatments ranging from $13-30 \%$. There may be a nutrient imbalance due to the overlyhigh accumulation of $\mathrm{K}$. Too high concentration of $\mathrm{K}$ in soil is likely to reduce $\mathrm{Ca}$ and $\mathrm{Mg}$ uptake by plantsso that the growth is disturbed (Mutscher, 1995). The K fertilizer application $\left(200 \mathrm{~kg} \mathrm{ha}^{-1}\right)$ as well as biochar added with potassium fertilizer at the rate of $50-200 \mathrm{~kg} \mathrm{ha}^{-1}$, yield dried maize of 5.78-7.02 $\mathrm{Mg} \mathrm{ha}^{-1}$. The measurement of biochar effectiveness value is presented in Table 3 . The biochar application without $\mathrm{K}$ fertilizer and with $\mathrm{K}$ fertilizer at the rate of $50-200 \mathrm{~kg} \mathrm{ha}^{-1}$ does not significantly affect the relative agronomic effectiveness (RAE). The effectiveness is a result that emphasize on the effects / results and it is less concerned about the rate of $\mathrm{K}$ fertilizer used to obtain the maize. The highest value of RAE (137\%) is obtained from biochar with $\mathrm{K}$ fertilizer at the rate of $50 \mathrm{Mg} \mathrm{ha}^{-1}$. The reduction of $\mathrm{K}$ fertilizer rate as much as $3 / 4$ of the standard rate yield no different result from other treatments. This shows the role of biochar for plants when combined with the use of low rate of $\mathrm{K}$ fertilizer. The RAE value of $\mathrm{K}$ fertilizer use is lower than biochar with $\mathrm{K}$ fertilizer at various rate $(111-137 \%)$. 
Table 2. Mean of result component, dried maize result, and relative agronomic effectiveness (RAE)

\begin{tabular}{lccccc}
\hline Treatment & $\begin{array}{c}\text { Weight of 1000 grain Cob Diameter } \\
(\mathrm{g})\end{array}$ & $(\mathrm{cm})$ & $(\mathrm{cm})$ & $\begin{array}{c}\text { Cob Length } \\
\left(\mathrm{Mg} \mathrm{ha}^{-1}\right)\end{array}$ & $\begin{array}{c}\text { Dried Corn Results } \\
(\%)\end{array}$ \\
\hline K1 & 238.30 & 4.57 & 17.86 & 5.46 & 100 \\
$\mathrm{BK} 0$ & 242.93 & 4.97 & 20.71 & 6.24 & 124 \\
$\mathrm{BK} 1 / 4$ & 250.77 & 4.85 & 19.75 & 7.02 & 137 \\
$\mathrm{BK} 1 / 2$ & 248.13 & 4.90 & 20.46 & 5.78 & 111 \\
$\mathrm{BK} 3 / 4$ & 253.40 & 4.78 & 19.89 & 6.26 & 122 \\
BK1 & 251.80 & 4.84 & 19.91 & 6.57 & 130 \\
\hline
\end{tabular}

Means followed by the same letters in the same column are not significantly different $(\mathrm{p}=0.05)$.

\subsection{Economic Feasibility of Maize Cultivation With Biochar and Potassium Fertilizer}

Maize cultivation with and without biochar combined with inorganic fertilizers, shows economically feasible (R/C 1.5-1.8). Biochar with $\mathrm{K}$ fertilizer at the rate of $50 \mathrm{~kg} \mathrm{ha}^{-1}(\mathrm{BK} 1 / 4)$ is the best technically and economically because it yield high production level $\left(7.02 \mathrm{Mg} \mathrm{ha}^{-1}\right)$, highest value of sales (revenue) which is IDR $19,305,000 \mathrm{ha}^{-1}$, highest income which is IDR 8,663,000 ha ${ }^{-1}$ and highest economic feasibility (R/C) which is 1.8 (Table 3). A study assessing the impact of agronomic and cost to put biochar into the soil at various rate has been done Woolf (2008). Technically the benefits of biochar application are: it is easy for farmers to implement, reduce the use of $\mathrm{K}$ fertilizer rate, lower production costs, help to solve problems of inorganic fertilizers scarcity, simple production installation, easy production and application on farming land, abundant raw materials in the surrounding farm, and capable of using agricultural waste which has been wasted. labor use is categorized as productive because the wages paid is less than the contribution of the labor to the cultivation business. The highest labor productivity is on the treatment without biochar which is only uses inorganic fertilizers (K1). The productivity based on the revenue and production are amounted to IDR $82,139 / \mathrm{HKO}$ and $29.87 \mathrm{~kg} / \mathrm{HKO}$ with the wage of IDR 30,000/HKO (below the productivity value). This is because there is a difference in using the labors i.e. the $182.8 \mathrm{HKO} \mathrm{ha}^{-1}$ (without biochar) and $400.8 \mathrm{HKO} \mathrm{ha}^{-1}$ (with biochar). The use of labor on the cultivation business with biochar is high, because in the first year it is needed to provide necessary facilities and process of making biochar. The cost of biochar application on cultivation soils by Williams et al. (2010): The application of biochar with array method at the level of $2.5,5,10,25,50 \mathrm{Mg} \mathrm{ha}^{-1}$ with the cost in successive are $\$ 29, \$ 44, \$ 72, \$ 158, \$ 300 \mathrm{ha}^{-1}$. The cost depends on several variables including the rate of biochar application, depth of the trench, and operator efficiency. On biochar application at the rate of $5,10,25,50,75 \mathrm{Mg} \mathrm{ha}^{-1}$, with $2 \mathrm{~m}$ deep trench and excavation levels of 15 per minute per hectare, the cost in successive are $\$ 34, \$ 85, \$ 171, \$ 341$, dan $\$ 512$.

Table 3. Recapitulation of production, cost of farming business, price-selling of products, revenue, income and economic feasibility of maize farming business with biochar and potassium fertilizer dosage

\begin{tabular}{|c|c|c|c|c|c|c|c|c|c|}
\hline Treatment & $\begin{array}{l}\text { Production } \\
\left(\mathrm{Mg} \mathrm{ha}^{-1}\right)\end{array}$ & $\begin{array}{l}\text { Labor } \\
\text { Use } \\
\text { (HKO) }\end{array}$ & $\begin{array}{l}\text { Production } \\
\text { Cost } \\
(\text { IDR ha-1) }\end{array}$ & $\begin{array}{c}\text { Products } \\
\text { Selling Price } \\
\text { IDR } \mathrm{kg}^{-1}\end{array}$ & $\begin{array}{l}\text { Revenues } \\
\left(\text { IDR } \mathrm{ha}^{-1} \text { ) }\right.\end{array}$ & $\begin{array}{l}\text { Income } \\
\text { (IDR } \\
\mathrm{ha}^{-1} \text { ) }\end{array}$ & $\begin{array}{c}\text { Economic } \\
\text { Efficiency } \\
(\mathrm{R} / \mathrm{C})\end{array}$ & $\begin{array}{c}\text { Labor } \\
\text { Productivity } \\
\text { (IDR / HKO) }\end{array}$ & $\begin{array}{c}\text { Labor } \\
\text { Productivity } \\
(\mathrm{kg} / \mathrm{HKO})\end{array}$ \\
\hline K1 & 5.46 & 182.8 & $8,405,000$ & 2,750 & $15,015,000$ & $6,610,000$ & 1.8 & 82,139 & 29,87 \\
\hline BK0 & 6.24 & 400.8 & $10,417,000$ & 2,750 & $17,160,000$ & $6,743,000$ & 1.6 & 42,814 & 15,57 \\
\hline BK1/4 & 7.02 & 400.8 & $10,642,000$ & 2,750 & $19,305,000$ & $8,663,000$ & 1.8 & 48,166 & 17,51 \\
\hline BK1/2 & 5.78 & 400.8 & $10,867,000$ & 2,750 & $15,895,000$ & $5,028,000$ & 1.5 & 39,658 & 14,42 \\
\hline $\mathrm{BK} 3 / 4$ & 6.26 & 400.8 & $11,092,000$ & 2,750 & $17,215,000$ & $6,123,000$ & 1.6 & 42,952 & 15,62 \\
\hline BK1 & 6.57 & 400.8 & $11,317,000$ & 2,750 & $18,067,500$ & $6,750,500$ & 1.6 & 45,079 & 16,39 \\
\hline
\end{tabular}

\subsection{Biochar and Potassium Fertilizers Dosage to Nutrient Element Availability}

The biochar application is significantly different than without biochar (control and treatment K1) in terms of potassium (total and available), calcium, nitrogen and phosphorus (Table 4). After harvest, nutrient from 
treatments $\mathrm{K} 1$ is not different from control. The i nutrient taken through the harvest lead to the reduced availability of nutrient provided by fertilizers. However, biochar cause the nutrient decrease to be low. The results show that the nutrient availability increases by biochar application, which is $69-89 \%(\mathrm{~K}+), 61-70 \%\left(\mathrm{Ca}^{++}\right), 39-53 \%(\mathrm{~N}$ total), $179-208 \%(\mathrm{P})$, and 14-184 \% (K total). The results are in line with Major et al., 2010 who reports that the availability of $\mathrm{K}, \mathrm{Ca}, \mathrm{Mg}$ increased in the following years after biochar application of wood and $\mathrm{KCl}$ fertilizer. $\mathrm{K}$ level increases after: 37 days of wood biochar application in Oxisol Amazon Brazilian (Lehmann et al., 2003) ; 42 days after biochar application of green waste in Alfisol (Chan et al., 2007); and 75 days after biochar application (Rondon et al., 2007). In contrast, Steiner et al. (2007) does not observe that K availability becomes greater after one cultivation season with wood biochar application on Oxisol. The availability of $\mathrm{N}$ in the soil increases with biochar application (Steiner et al., 2008; Widowati et al., 2012). One time biochar application will be useful in the next planting season. Long-term effects of biochar on nutrient availability, due to the increased surface of oxidation and cation exchange capacity (CEC) (Liang et al., 2006) and can lead to greater nutrient retention.

\section{Conclusions}

The results show the sole application of biochar increased maize production $\left(6.24 \mathrm{Mg} \mathrm{ha}^{-1}\right)$ by $14 \%$ compared to the sole application of $\mathrm{KCl}$ fertilizer $\left(5.45 \mathrm{Mg} \mathrm{ha}^{-1}\right)$. In contrast, dual application of biochar and $75 \%$ lower rate of $\mathrm{KCl}$ fertilizer application increased maize production by $29 \%$. Application of biochar and $\mathrm{KCl}$ fertilizer at the rate of $50 \mathrm{~kg} \mathrm{ha}^{-1}$ resulted in the highest relative agronomic effectiveness (137\%) and $\mathrm{K}$ fertilizer efficiency (18\%). This application rate was also superior both technically and economically as assessed in terms of production (7.02 $\mathrm{Mg} \mathrm{ha}^{-1}$ ), value of sales (revenue; IDR 19,305 million ha ${ }^{-1}$ ), income (IDR 8,663 million ha ${ }^{-1}$ ), and economic feasibility $(\mathrm{R} / \mathrm{C}, 1.8)$.

Table 4. Mean of N levels, $\mathrm{P}, \mathrm{K}, \mathrm{K}^{+}, \mathrm{Ca}^{2+}$, and $\mathrm{Mg}^{2+}$ in Soil after Harvest Time

\begin{tabular}{llllccc}
\hline Treatment & $\mathrm{N}(\%)$ & $\begin{array}{l}\text { Available } \mathrm{P} \\
(\mathrm{ppm})\end{array}$ & $\mathrm{K}(\%)$ & $\begin{array}{c}\text { Exchangeable } \mathrm{K}^{+} \\
(\mathrm{cmol} \mathrm{kg})\end{array}$ & $\begin{array}{c}\text { Exchangeable } \mathrm{Ca}^{2+} \\
\left(\mathrm{cmol} \mathrm{kg}^{-1}\right)\end{array}$ & $\begin{array}{c}\text { Exchangeable } \mathrm{Mg}^{2+} \\
\left(\mathrm{cmol} \mathrm{kg}^{-1}\right)\end{array}$ \\
\hline Control & $0.14 \mathrm{a}$ & $34.90 \mathrm{a}$ & $30.91 \mathrm{a}$ & $0.25 \mathrm{a}$ & $14.30 \mathrm{a}$ & 1.15 \\
$\mathrm{~K} 1$ & $0.17 \mathrm{a}$ & $59.97 \mathrm{~b}$ & $50.20 \mathrm{ab}$ & $0.46 \mathrm{a}$ & $17.08 \mathrm{a}$ & 1.27 \\
$\mathrm{BK} 0$ & $0.24 \mathrm{c}$ & $167.42 \mathrm{c}$ & $122.86 \mathrm{c}$ & $0.88 \mathrm{c}$ & $27.44 \mathrm{bc}$ & 1.27 \\
$\mathrm{BK} 1 / 4$ & $0.26 \mathrm{c}$ & $173.25 \mathrm{c}$ & $142.36 \mathrm{c}$ & $0.82 \mathrm{c}$ & $29.08 \mathrm{c}$ & 1.28 \\
$\mathrm{BK} 1 / 2$ & $0.24 \mathrm{c}$ & $180.51 \mathrm{c}$ & $63.25 \mathrm{~b}$ & $0.78 \mathrm{bc}$ & $29.06 \mathrm{c}$ & 1.55 \\
$\mathrm{BK} 3 / 4$ & $0.24 \mathrm{c}$ & $183.31 \mathrm{c}$ & $57.12 \mathrm{ab}$ & $0.83 \mathrm{c}$ & $27.57 \mathrm{c}$ & 1.52 \\
$\mathrm{BK} 1$ & $0.23 \mathrm{~b}$ & $184.62 \mathrm{c}$ & $44.50 \mathrm{ab}$ & $0.82 \mathrm{c}$ & $27.44 \mathrm{bc}$ & 1.50 \\
\hline
\end{tabular}

Means followed by the same letters in the same column are not significantly different $(\mathrm{p}=0.05)$.

\section{Acknowledgements}

The gratitude is presented to General Directorate of Higher Education Department of Education and Culture, which has been providing research funding of Competitive Grant in 2012.

\section{References}

Ahmedna, M., Johns, M. M., Clarke, S. J., Marshall, W. E., \& Rao, R. M. (1977). Potential of agriculture by-product-based activated carbons for use in raw sugar decolorization. Journal Science Food Agriculture, $75,117-124$.

Amonette, J. E., \& Joseph, S. (2009). Characteristics of biochar: microchemical properties. Chapter 3. In J. Lehmann, \& S. Joseph (Eds.), Biochar for environmental management science and technology (pp. 33-52). London: Earthscan.

ASTM. (2006). Petroleum Products, Lubricants, and Fossil Fuels: Gaseous Fuels; Coal and Coke. ASTM Inter, West Conshohocken, PA.

Baligar, V. C., \& Bennett, O. L. (1986). Outlook on fertilizer use efficiency in the tropics. Fertil ity Research, 10, 83-96. http://dx.doi.org/10.1007/BF01073907

Baronti, S., Giorgio, A., Gemini, D. V., Filippo, D. G., Guido, F., Lorenzo, G., ... Francesco, P. V. (2010). The biochar option to improve plant yields: first results from some field and pot experiments in Italy the biochar 
option to improve plant yields: first results from some field and pot experiments in Italy. Italial Journal.of Agronomy. / River Agronomy., 5, 3-11.

Brady, C. N. (1992). The Nature and Properties of Soil. New York: Macmillan Pub. Co.

Chan, K. Y., Van Zwieten, L., Meszaros, I., Downie, A., \& Joseph, S. (2007). Agronomic values of greenwaste biochar as a soil amendment. Australia Journal of Soil Research, 45, 629-634. http://dx.doi.org/10.1071/SR07109

Chintala, R., Mollinedo, J., Schumacher, T. E., Malo, D. D., Papiernik, S., Clay, D. E., ...Gulbrandson, D. W. (2013). Nitrate sorption and desorption by biochars produced from microwave pyrolysis. Microporous and Mesoporous Materials, 179, 250-257. http://dx.doi.org/10.1016/j.micromeso.2013.05.023

Cooke, G. W. (1985). Potassium in agriculture systems of the humid tropics: an introduction to the colloquium. In Proceeding of the $19^{\text {th }}$ Colloquium of the International Potash. Institute, Bangkok.

Downie, A., Crosky, A., \& Munroe, P. (2009). Physical properties of biochar. In J. Lehmann \& S. Joseph (Eds.), Biochar for Environmental Management: Science and Technology (pp. 13-32). United Kingdom: Earthscan.

Garrity, D. P. (2004). Agroforestry and the achievement of the millenium development goals. Agroforest System, 61, 5-17. http://dx.doi.org/10.1023/B:AGFO.0000028986.37502.7c

Ghosal, P. K., Chakraborty, T., Bhattacharya, B., \& Bagchi, D. K. (2003). Relative agronomic effectiveness of phosphate rocks and P adsorption characteristics of an Oxic Rhodustalf in Eastern India. Journal of Plant Nutrition and Soil Science, 166, 750-755. http://dx.doi.org/10.1002/jpln.200321034

Gundale, M. J., \& DeLuca, T. H. (2007). Charcoal effects on soil solution hemistry and growth of Koeleria macrantha in the ponderosa pine/Douglas-fir cosystem. Biology Fertilizer of Soils, 43, 303-311. http://dx.doi.org/10.1007/s00374-006-0106-5

Jenkinson, D. S., \& Ayanaba, A. (1977). Decomposition of carbon-14 labeled plant material under tropical conditions. Soil Science Society of America Journal, 41, 912-915. http://dx.doi.org/10.2136/sssaj1977.03615995004100050020x

Krull, E. (2009). Stabilisation of organic carbon in soil through biochar production. In: An analysis of greenhouse gas mitigation and carbon sequestration opportunities from rural land use, CSIRO National Research Flagships: Sustainable Agriculture. Retrieved from www.csiro.au/files/files/prdz.pdf

Lehmann, J., da Silva, J. J. P., Steiner, C., Nehls, T., Zech, W., \& Glaser, B. (2003). Nutrient availability and leaching in an archaeological Anthrosol and a Ferralsol of the Central Amazon basin: fertilizer, manure and charcoal amendments. Plant Soil, 249, 343-357. http://dx.doi.org/10.1023/A:1022833116184

Liang, B., Lehmann, J., Solomon, D., Kinyangi, J., Grossman, J., O’Neill, B., ... Neves, E. G. (2006). Black carbon increases cation exchange capacity in soils. Soil Science Society of America Journal, 70, 1719-30. http://dx.doi.org/10.2136/sssaj2005.0383

Major, J., M. Rondon, D. Molina, Susan, J. R., \& Lehmann, J. (2010). Maize yield and nutrition during 4 years after biochar application to a Colombian savanna oxisol. Plant Soil, 333, 117-128. http://dx.doi.org/10.1007/s11104-010-0327-0.

Masulili, A., Utomo, W. H., \& Syechfani, M. S. (2010). Rice husk biochar for rice based cropping system in acid soil 1 . The characteristics of rice husk biochar and its influence on the properties of acid sulfate soils and rice growth in West Kalimantan, Indonesia. Journal of Agricultural Science, 2(1), 39-47.

Mutscher, H. (1995). Measurement and assessment of soil potassium. IPI Res. Topics No. 4. Int. Potash Inst.

Preston, C. M., \& Schmidt, M. W. I. (2006). Black (pyrogenic) carbon: a synthesis of current knowledge and uncertainties with special consideration of boreal regions. Biogeosciences, 3, 397-420. http://dx.doi.org/10.5194/bg-3-397-2006

Rondon, M., Lehmann, J., Ramirez, J., \& Hurtado, M. (2007). Biological nitrogen fixation by common beans (Phaseolus vulgaris L.) increases with bio-char additions. Biology Fertilizer of Soils, 43, 699-708. http://dx.doi.org/10.1007/s00374-006-0152-z

Schmidt, M. W. I., \& Noack, A. G. (2000). Black carbon in soils and sediments: analysis, distribution, implications and current challenges. Global Biogeochemical Cycles, 14, 777-793. http://dx.doi.org/10.1029/1999GB001208 
Sohi, S. P, Krull, E, Lopez-Capel, E., \& Bol, R. (2010). Chapter 2-A review of biochar and its use and function in soil. Advances in Agronomy, 105, 47-82. http://dx.doi.org/10.1016/S0065-2113(10)05002-9

Soil Survey Laboratory Staff. (1992). Soil survey laboratory methods manual. Soil Survey Investigation Report No. 42, Version 2.0, USDA.

Steiner, C, Teixeira, W. G, Lehmann, J., Nehls, T., de Macedo, J. L. V., Blum, W. E. H., \& Zech, W. (2007). Long term effects of manure, charcoal and mineral fertilization on crop production and fertility on a highly weathered Central mazonian upland soil. Plant and Soil, 291, 275-290. http://dx.doi.org/10.1007/s11104-007-9193-9

Steiner, C., Glaser, B., Teixeira, W. G., Lehmann, J., Blum, W. E. H., \& Zech, W. (2008). Nitrogen retention and plant uptake on a highly weathered central Amazonian Ferraisol amended with compost and charcoal. Journal of Plant Nutrition and Soil Science, 171, 893-899. http://dx.doi.org/10.1002/jpln.200625199

Thomson, B. (2008). Potassium. Retrieved 23 Desember, 2008, from www.back-to-basic.net/efu/pdfs/ptassium.pdf

Warnock, D. D., Lehmann, J, Kuyper, T. W., \& Rillig, M. C. (2007). Mycorrhizal responses to biochar in soil-concepts and mechanisms. Plant and Soil, 300, 9-20. http://dx.doi.org/10.1007/s11104-007-9391-5

Widowati, Utomo, W. H., Soehono, L. A., \& Guritno, B. (2011). Effect of biochar on the Release and Loss of Nitrogen from Urea Fertilization. Journal of Agriculture and Food Technology, 1, 127-132.

Widowati, Utomo, W. H., Soehono, L. A., \& Guritno, B. (2012). The Effect of Biochar on the Growth and N Fertilizer Requirement of Maize (Zea mays L.) in Green House Experiment. Journal of Agricultural Science, 4, 255-262.

Williams, M. M., \& Arnott, J. C. (2010). A comparison of variable economic costs associated with two proposed biochar application methods. Annals of Environmental Science, 4, 23-30.

Witt, C., Pasuquin, J. M., \& Dobermann, A. (2006). To wards a site-specific nutrient management approach for maize in Asia. Better Crops, 90, 28-31.

Woolf, D. (2008). Biochar as a soil amendment: A review of the environmental implications. Swansea University, UK. Retrieved May 4, 2010, from http://orgprints.org/13268/01/Biochar_as_a_soil_amendment_-_a_review.pdf

\section{Copyrights}

Copyright for this article is retained by the author(s), with first publication rights granted to the journal.

This is an open-access article distributed under the terms and conditions of the Creative Commons Attribution license (http://creativecommons.org/licenses/by/3.0/). 